Article

\title{
Pilot-Scale Experimental Study on Impacts of Biomass Cofiring Methods to NOx Emission from Pulverized Coal Boilers-Part 2: NOx Reduction Capability through Reburning versus Cofiring
}

\author{
Taeyoung Chae ${ }^{1}$, Jaewook Lee ${ }^{1}$, Yongwoon Lee ${ }^{1}$, Won Yang ${ }^{1,2, *}$ and Changkook Ryu ${ }^{3}$ \\ 1 Carbon Neutral Technology R\&D Department, Korea Institute of Industrial Technology, \\ Cheonan 31056, Korea; hitae0@kitech.re.kr (T.C.); lee_jw@kitech.re.kr (J.L.); ywlee8131@kitech.re.kr (Y.L.) \\ 2 Department of Clean Process and Energy System Engineering, University of Science and Technology, \\ Daejeon 34113, Korea \\ 3 School of Mechanical Engineering, Sungkyunkwan University, Suwon 16419, Korea; cryu@skku.edu \\ * Correspondence: yangwon@kitech.re.kr
}

check for updates

Citation: Chae, T.; Lee, J.; Lee, Y.; Yang, W.; Ryu, C. Pilot-Scale Experimental Study on Impacts of Biomass Cofiring Methods to NOx Emission from Pulverized Coal Boilers-Part 2: NOx Reduction Capability through Reburning versus Cofiring. Energies 2021, 14, 6552. https://doi.org/10.3390/en14206552

Academic Editor: Adam Smoliński

Received: 18 September 2021

Accepted: 8 October 2021

Published: 12 October 2021

Publisher's Note: MDPI stays neutral with regard to jurisdictional claims in published maps and institutional affiliations.

Copyright: (C) 2021 by the authors. Licensee MDPI, Basel, Switzerland. This article is an open access article distributed under the terms and conditions of the Creative Commons Attribution (CC BY) license (https:/ / creativecommons.org/licenses/by/ $4.0 /)$.

\begin{abstract}
In this study the NOx reduction capability of reburning three biomasses (i.e., wood pellet, torrefied biomass, and empty fruit bunch) via 12 cases (i.e., four reburning ratios for every biomass) is investigated in a $1 \mathrm{MW}_{\mathrm{th}}$-scale pilot-scale furnace. These reburning cases are compared with 12 cofiring cases presented in the Part 1 paper on a consistent basis. It is found that, for every cost to purchase and prepare biomass, reburning technology provides significantly better NOx abatement performance than cofiring (up to 3.4 times). NOx reduction effectiveness as high as 4.9 could be achieved by reburning, which means the percent of NOx abatement could be 4.9 times higher than the percent of reburning ratio. It is found that the highest NOx reduction per thermal unit of biomass happens at the lowest reburning ratio, and increasing the reburning ratio leads to a reduction in NOx abatement effectiveness in an exponential decay manner. Unlike cofiring technology, reburning was found to have little dependence on the fuel characteristics, such as fuel ratio or fuel-N, when it comes to NOx abatement potential.
\end{abstract}

Keywords: biomass cofiring; air staging; NOx emission; dual fuel burner; NOx reduction effectiveness

\section{Introduction}

Reducing nitrogen oxides (NOx) emission is one of the major issues in most combustion systems. Fuel NOx, formed from nitrogen in fuel, has been identified to be the main source of $\mathrm{NOx}$ (mainly $\mathrm{NO}$ and, to a much lesser extent, $\mathrm{NO}_{2}$ and $\mathrm{N}_{2} \mathrm{O}$ ) formation pathway in the combustion of coal [1-3] and biomass [4,5].

NO formation resulting from coal/biomass combustion could be explained within the two fuel conversion stages. In the first stage (i.e., devolatilization), fuel-N is liberated as $\mathrm{HCN}$ and $\mathrm{NH}_{\mathrm{i}}$. There are relations between the share of $\mathrm{HCN}$ vs. $\mathrm{NH}_{\mathrm{i}}$ and fuel characteristics. Depending on the level of oxygen in the reaction zone these intermediates can play the contradictory role of destructing or generating NOx. At the presence of oxygen, $\mathrm{HCN}$ and $\mathrm{NH}_{\mathrm{i}}$ lead to $\mathrm{NOx}$ generation, while the absence of oxygen leads to the reaction of these intermediates with $\mathrm{NO}$ and production of molecular nitrogen, and their role as NOx destruction agents. In the second stage of fuel conversion (i.e., char combustion), char-N reacts with oxygen and produces NOx. While usually 20 percent of total fuel-N is nested in char [6], it is the factor that limits the NOx reduction capability of primary NOx measures, such as low-NOx burner and air staging [7,8]. Thus, this share of fuel-N is the main source of $\mathrm{NO}$ emission in coal power plants.

There are several primary (in-furnace) and secondary NOx control measurements in coal power plants. For the secondary NOx control technologies, all of them are forms of flue gas treatment processes. The selective catalytic reactor (SCR) is the most commonly 
used secondary measure in coal power plants, with efficiency of $90 \%$ and higher if proper operation temperature and ammonia mixing is imposed. Primary measures, on the other hand, try to reduce NOx mainly by manipulating the combustion process. These are low NOx burner, air staging (overfire air), and fuel staging (reburning).

Reburning is introduced by $[9,10]$ based on the principles developed by Myerson et al. [11]. The main idea in reburning as a primary NOx reduction measure is to provide a locally fuel-rich zone, which, in turn, leads to production of $\mathrm{CH}_{\mathrm{i}}(\mathrm{i}=1,2$, or 3) radicals in the region. $\mathrm{CH}_{\mathrm{i}}$ can react with previously generated NOx species, which, finally, favor production of $\mathrm{N}_{2}$. To be more precise, it should be said that $\mathrm{CH}_{i}$ radicals react with $\mathrm{NO}$ to produce intermediates, such as $\mathrm{HCN}$ and $\mathrm{NH}_{\mathrm{i}}$ [12]. Since the reaction zone is fuel rich and oxygen deficient, $\mathrm{HCN}$ and $\mathrm{NH}_{\mathrm{i}}$ intermediates promote further consumption of $\mathrm{NO}$ and production of $\mathrm{N}_{2}$ rather than consumption of radical $\mathrm{O}$ and production of $\mathrm{NO}$. In pulverized coal combustion systems, the reburning system requires a separated feeding system for reburning fuel. Figure 1 shows it in a schematic diagram compared with cofiring and air-staged combustion systems. The reburning fuel can be any type of fuel, such as gas fuel, e.g., natural gas or syngas, liquid fuel, and solid fuels, e.g., biomass or pulverized coal itself. They can make a reduction zone above the burner zone, and are burned out by separated overfired air (SOFA). It can be combined with biomass cofiring, as well as air-staged combustion. The performance of the reburning is definitely highly dependent on the characteristics of reburning fuel.

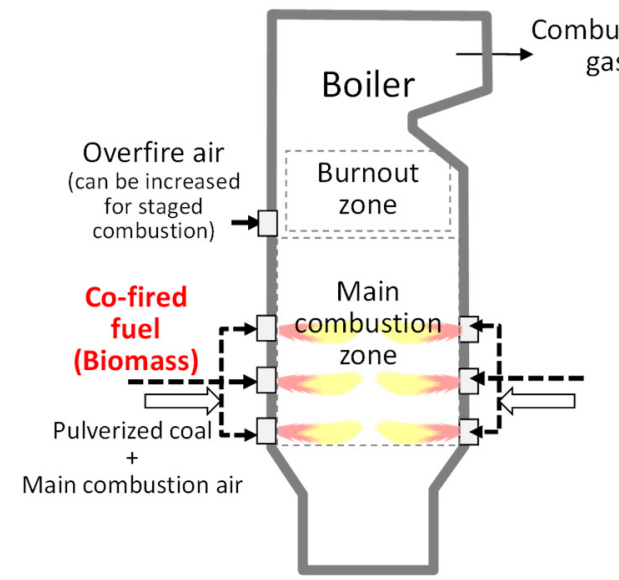

(a)

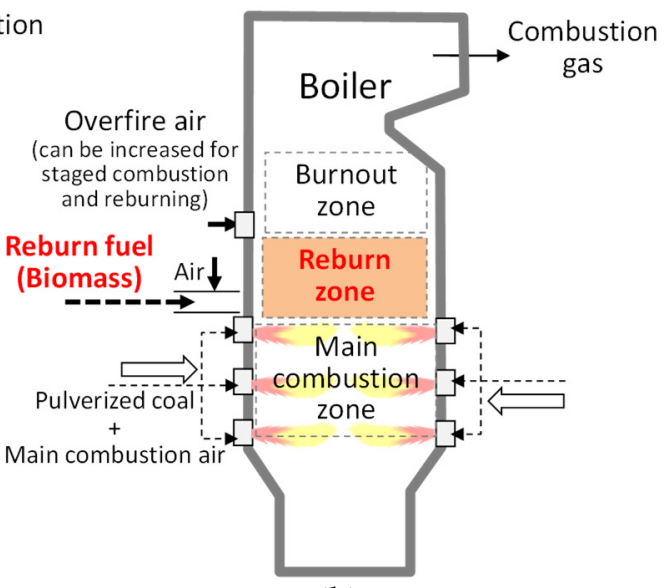

(b)

Figure 1. Conceptual diagram of the biomass cofiring and reburning in a pulverized coal boiler: (a) biomass cofiring; (b) biomass reburning.

The performance of natural gas (e.g., [13,14]), coal (e.g., [15,16]), and biomass (e.g., [12,17]) as reburning fuel were investigated for the purpose of NOx reduction. In theory, since pyrolysis of woody biomass mostly consists of $\mathrm{C}-\mathrm{O}$ bonds and its combustion will mostly lead to $\mathrm{CO}$ fragments (not $\mathrm{CH}_{\mathrm{i}}$ ), it is believed that biomass must have less NOx reduction capability compared to natural gas and coal when used as reburn fuel [12]. However, in practice, reburning wood has been shown to be as capable as other typical reburn fuels, such as conventional gas fuels or coal [12]. The reason has been said to be the reaction between $\mathrm{CO}$ and $\mathrm{NO}$, which leads to $\mathrm{CO}_{2}$ and $\mathrm{N}_{2}[7,18]$. In this scenario, char plays the role of catalyzer. Since the reaction is boosted by char, it happens either on char surface or inside char pores and could reduce NOx resulting from char-N [18,19].

There has been a range of studies on different aspects of biomass reburning with respect to NOx abatement. Harding and Adams [12] performed a comprehensive study on 10 influential parameters, including stoichiometric ratio of reburn zone, wood type (i.e., softwood vs. hardwood), reburn fuel injection temperature, reburn fuel particle size, reburn fuel carrier fluid, wood moisture content, reburning residence time, initial NOx level, and overall firing rate. They concluded that biomass has the same or even higher 
NOx abatement capability depending on condition [12]. Ballester et al. [20] have performed an almost similar study as [12] and reached almost similar conclusions regarding the effectiveness of biomass reburning compared to natural gas, influence of reburn zone stoichiometric ratio, and reburn fuel residence time. The authors of [21-24] have also reached the same conclusion when it comes to the NOx reduction capability of biomass compared with gas and coal. Adams and Harding [16] performed a study in a cyclonefired boiler and concluded that flue gas is a more effective carrier gas than air when it comes to NOx reduction capability of biomass as reburn fuel. Casaca and Costa [24] conducted a study on the effect of reburn fuel particle size on the NOx reduction efficiency in a small-scale furnace using rice husks. They concluded that there is an optimum particle size leading to maximum NOx reduction [24]. Particles bigger and smaller than the optimum size would decrease the NOx reduction capability. Vilas et al. [25] have been among pioneers investigating biomass reburning in full-scale facility. They [26] studied the influence of biomass type, volatile composition, and, especially, biomass char characteristics on NOx reduction capabilities during reburning. Shu et al. [26] conducted a parametric study in a one-dimensional dropping tube furnace and concluded that NO reduction in biomass and its char is improved by reduction in reburn zone stoichiometric ratio and increase in volatile content, reaction temperature, residence time, and initial NO concentration. Hodzic et al. [27] conducted a research under air staging conditions and reburning of both woody biomass and natural gas. They aimed to study the influential parameters, such as combustion temperature, overall excess air ratio, and depth of air staging, as well as fuel composition [27]. They have reported the feasibility of reducing cost of denitrification through a combination of primary NOx measures, such as air and fuel staging in a multi-fuel system, instead of using secondary NOx measures, such as SCR or SNCR [27]. Lu et al. [28] performed a parametric study on the effect of biomass type, stoichiometric ratio, and temperature in the reburn zone, reburn fuel particle size, and fraction of reburn fuel in an entrained flow reactor. Zhou et al. [29] studied the impact of biomass cofiring on boiler condition and flame structure and the impact of biomass reburning on combustion performance. However, there is no direct comparison between biomass reburning and cofiring with regard to their NOx reduction capabilities on a constant basis.

Attempts to relate reburning biomass properties (volatile matter and nitrogen content) to its NOx reduction capabilities have led to contradictory discussions in the literature. For example, Lue et al. reports that cotton stalk (out of three other biomasses) with the highest volatile matter (dry ash free basis) and highest nitrogen brings the best NOx reduction efficiency. They argue that these two characteristics help liberation of more NOx-reducing nitrogenous species, such as $\mathrm{NH}_{\mathrm{i}}$ and $\mathrm{HCN}$, in the oxygen-deficient environment. However, their other results do not approve such an argument. For example, we see that rice straw with higher volatile matter and higher nitrogen content than rice husk has lower NOx reduction capability. Moreover, in the literature, it is believed that reburning performance, in general, benefits from lower nitrogen of biomass as reburn fuel (e.g., [12,22]). It has to be said that research, such as $[12,22,27,29]$, agreed on the positive effect of biomass volatile matter when it is used as reburn fuel. However, identifying the role of volatile matter becomes complex when comparing biomass with coal as reburn fuels. It is sensible because reburning coal and biomass leads to NOx reduction from totally different chemical pathways, as described prior in this introduction.

There are several benefits in co-utilization of biomass in coal-fired boilers. Regardless of the co-utilization strategy applied, it leads to $\mathrm{CO}_{2}$ and $\mathrm{SOx}$ reduction and, if applied properly, NOx reduction. Moreover, co-utilization technologies, such as cofiring and reburning, could be applied to the currently operating systems with minimal modifications and retrofitting. On the other hand, there are drawbacks involved, including higher fuel, transportation and preparation costs, modification costs (higher for reburning than cofiring), and slagging/fouling issues. Considering these competing effects, there should be studies comparing NOx reduction capability of biomass utilized in less expensive 
cofiring technology versus more expensive reburning technology. This provides a basis for cost-benefit analysis of utilizing biomass in coal-fired power stations.

In this paper, a comparison between the NOx reduction capability of biomass through two different co-utilization technologies (i.e., cofiring and reburning) under air staging condition has been studied. As it is clear in the above literature review, the absence of such study is conspicuous and can provide a basis for cost-benefit trade-offs when considering the selection of biomass co-utilization strategy. The cofiring results are presented in the Part 1 paper. Three different biomasses (i.e., wood pellet, torrefied biomass, and empty fruit bunch), with different nitrogen content and fuel ratios (ratio between fixed carbon and volatile matter), are considered in order to investigate effects of fuel properties to the NOx reduction capability of biomass in reburning technology.

\section{Experimental Setup and Conditions}

Figure 2 depicts the schematic and important dimensions of the pilot-scale test facility. It consists of a furnace, fuel/oxidant systems, and post-treatment units consisting of dust collection and flue gas treatment facilities. While furnace has wall firing and tangential firing capabilities, for this study, the wall-fired burners are installed on two opposing sides (i.e., a total of 4 burners). LNG burners are used for furnace warmup. There are three reburn ports only on the front wall. The rear wall does not host any reburning port. The vertical distance of these ports from the burners is $2.25 \mathrm{~m}$. For cofiring experiments in the Part 1 paper, these reburn ports are inactivated. Another difference between front and rear wall is the fact that burners on the rear wall are located at a relatively higher level $(0.6 \mathrm{~m})$. Five OFA ports are located on each wall (i.e., a total of 10 ports) at a vertical distance of 3.55 and $2.95 \mathrm{~m}$ from burners on the front and rear walls, respectively. The biomass supply system is separate from the coal supply facility. This means that, even for cofiring cases, the coal and biomass are not premixed and they are injected to the furnace through separate ports. It must be mentioned that, in the cofiring scenario, a dual fuel burner has been applied, in which coal and biomass are supplied through different ports. Such a cofiring arrangement has proved to have more transparent NOx reduction effects than co-injecting the fuels from a single port. While 4 tangential vane swirl burners have a maximum capacity of $1.2 \mathrm{MW}_{\text {th }}$, only $1 \mathrm{MW}$ thermal load is usually given to the system. More detailed information about burner technology and other facilities, such as air preheater, and measurement techniques are available in the Part 1 paper.

Three biomasses (i.e., wood pellet, WP, torrefied biomass, TB, and empty fruit bunch, EFB), along with Adaro sub-bituminous coal, are considered for this study. Their compositions are summarized in the Part 1 paper.

Four fuel substitution ratios (i.e., $5 \%, 10 \%, 15 \%$, and $20 \%$ ) have been considered to study the NOx reduction performance of biomass through two co-utilization technologies (i.e., co-firing and reburning). The overall stoichiometric ratio is fixed at 1.2, and the stoichiometric ratio at the primary combustion is fixed at 0.98 . Therefore, all cases are under the same air staging level. Table 1 summarizes all cofiring and reburning cases studied.

It should be emphasized that the NOx emission results of cofiring cases $(1 \sim 4,9 \sim 12$, and 17 20) have been previously described in the Part 1 paper and are brought here merely for comparison between NOx reduction performance of biomass reburning versus cofiring. All cases are compared against the base case (25th case), which burns 100\% Adaro coal without any reburning/cofiring of biomass. The base case is also under the same level of air staging as 24 other cases. The amount of NOx emission for the base case at $6 \% \mathrm{O}_{2}$ in dry flue gas is $277 \mathrm{ppm}$. This number will be the basis for calculating NOx reduction of 24 other cases. In this study, the location of reburn fuel and OFA ports is constant. The residence time is around $1.5 \mathrm{~s}$, which is higher than the normal residence time $(0.4 \sim 0.7 \mathrm{~s})$ of full-scale facilities [22]. Such a large residence time allows for full liberation of chemical fragments which might have a role in NOx reduction process. Brouwer et al. [30] studied reburning of wood with reburning residence time variations between 0.4 and $1.2 \mathrm{~s}$. They concluded that, while increasing residence time has a positive impact on NOx reduction, $90 \%$ of the 
NOx reduction due to reburning happens at the first $0.4 \mathrm{~s}$ [30]. Hence, while there might be small variations in volumetric flue gas production due to variation in the biomass heating value and moisture content, and, therefore, a small variation in residence time, the overall NOx reduction capability is not affected by such variation due to the significantly large residence time of biomasses in the reburning region.

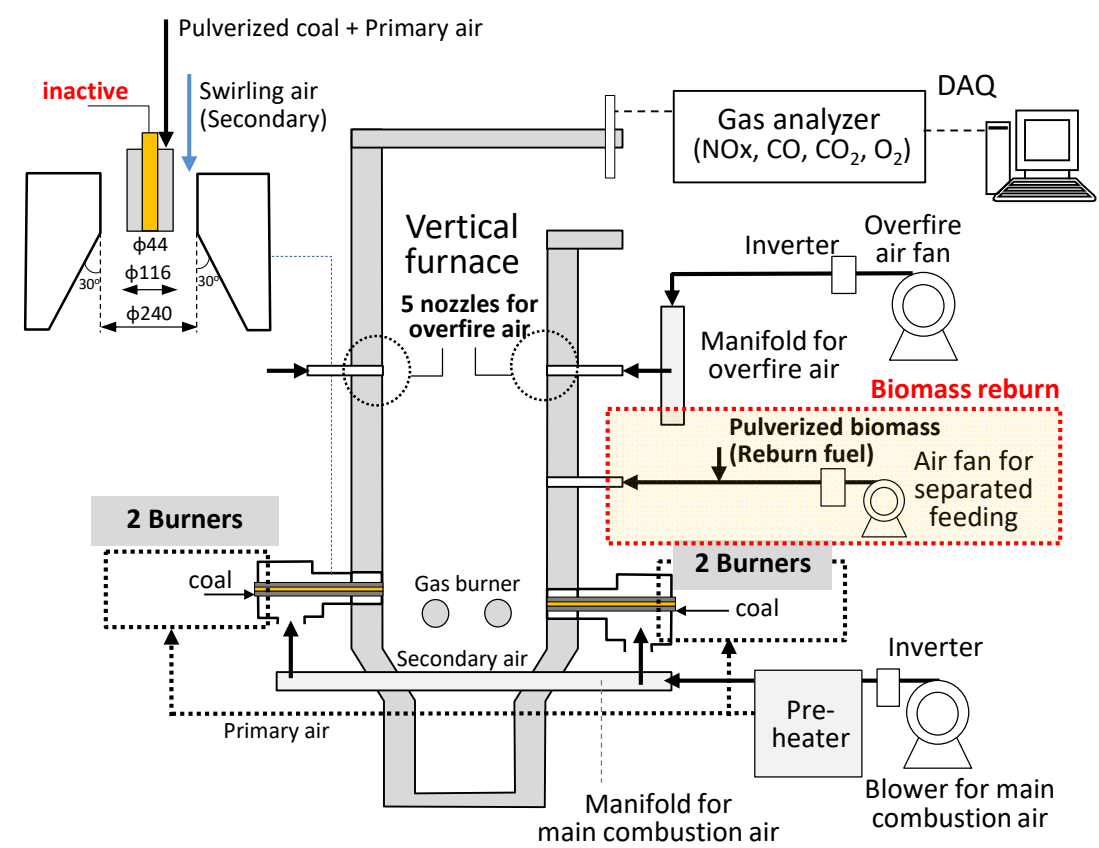

(a)

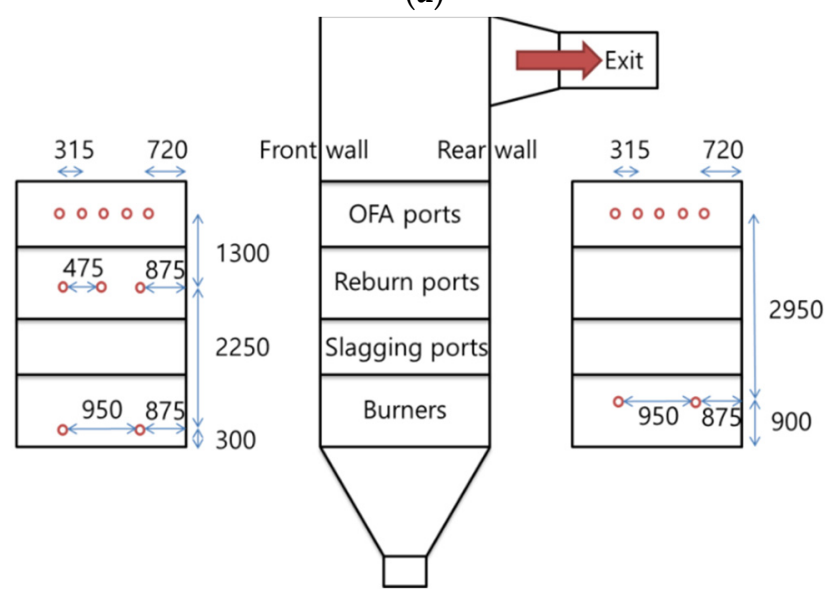

(b)

Figure 2. Experimental apparatus: (a) schematic diagram; (b) furnace dimensions.

Table 1. Details of fuel substitution ratios and for all case numbers.

\begin{tabular}{cccccc}
\hline \multirow{2}{*}{ Biomass } & Firing & \multicolumn{4}{c}{ Percent of Biomass Substitution } \\
\cline { 3 - 6 } & Technology & $\mathbf{5 \%}$ & $\mathbf{1 0 \%}$ & $\mathbf{1 5 \%}$ & $\mathbf{2 0} \%$ \\
\hline \multirow{2}{*}{ WP } & Cofiring * & $\# 1$ & $\# 2$ & $\# 3$ & $\# 4$ \\
& Reburning & $\# 5$ & $\# 6$ & $\# 7$ & $\# 8$ \\
\hline \multirow{2}{*}{ TB } & Cofiring * & $\# 9$ & $\# 10$ & $\# 11$ & $\# 12$ \\
& Reburning & $\# 13$ & $\# 14$ & $\# 15$ & $\# 16$ \\
\hline \multirow{2}{*}{ EFB } & Cofiring * & $\# 17$ & $\# 18$ & $\# 19$ & $\# 20$ \\
& Reburning & $\# 21$ & $\# 22$ & $\# 23$ & $\# 24$ \\
\hline
\end{tabular}

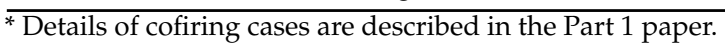




\section{Results and Discussion}

\subsection{Carbon Conversion of the Reburning versus Cofiring}

In all experimental cases, we checked combustion performance before discussion about $\mathrm{NOx}$ emission. Figure 3 shows concentrations of $\mathrm{O}_{2}$ and $\mathrm{CO}_{2}$ in the flue gas at furnace exit for various fuels, ratios of fuel replacements, and methods of fuel replacement (cofiring and reburning). In cases of WP (Figure 3a), we see that an almost similar value of $\mathrm{O}_{2}$ leads to a similar value of $\mathrm{CO}_{2}$ in cofiring cases. However, the $\mathrm{O}_{2}$ and $\mathrm{CO}_{2}$ concentrations of reburning cases show different behavior. This, for example, means lower $\mathrm{CO}_{2}$ is linked with higher $\mathrm{O}_{2}$, which leaves us with the conclusion that lower fuel is converted to energy. It also must be emphasized that the amount of $\mathrm{CO}$ for all cases is zero. Therefore, higher $\mathrm{O}_{2}$ and lower $\mathrm{CO}_{2}$, in some cases, suggest energy loss due to unburned carbon. In turn, it could be concluded that cofiring technology leads to slightly better fuel conversion than reburning technology, since cofiring cases led to lower $\mathrm{O}_{2}$ and higher $\mathrm{CO}_{2}$ when WP is utilized. Figure $3 \mathrm{~b}$ shows the $\mathrm{O}_{2}$ and $\mathrm{CO}_{2}$ at furnace exit for TB cofiring and reburning. It reveals that almost the same level of $\mathrm{O}_{2}$ at furnace exit for both the cofiring and reburning cases leads to almost same level of $\mathrm{CO}_{2}$. Therefore, there is no significant difference between level of fuel conversion rate in the case of TB cofiring and reburning. However, in cases of EFB reburning (Figure 3c), $\mathrm{CO}_{2}$ concentration is decreased by $1 \%$ for higher replacement ratio, while there is no significant change for cofiring cases. The figure reveals higher $\mathrm{CO}_{2}$ and lower $\mathrm{O}_{2}$ in cofiring cases, which implies higher carbon conversion (combustion efficiency) compared with reburning cases. The same conclusion also has been driven for WP cases. For TB, however, the fuel conversion of both cases has been quite similar.

\subsection{NOx Reduction Behavior of Reburning versus Cofiring}

Figure 4 shows the amount of NOx emission at $6 \% \mathrm{O}_{2}$ in dry flue gas for different percentages of WP cofiring and reburning. It also shows the percent of NOx reduction by comparing the amount of NOx emission for every case with the base case (i.e., the case without cofiring and reburning; $277 \mathrm{ppm}$ NOx). Cofiring of 5, 10, 15, and 20 percent leads to 250, 225, 215, and 204 ppm of NOx, while these amounts of reburning are 215, 194, 172, and $143 \mathrm{ppm}$ of NOx, respectively. These numbers suggest that the percent of NOx reduction for cofiring cases are 10, 19, 22, and 26 for 5, 10, 15, and $20 \%$ fuel replacement. The same amount of fuel replacement as reburning leads to $22,30,38$, and $48 \%$ NOx reduction.

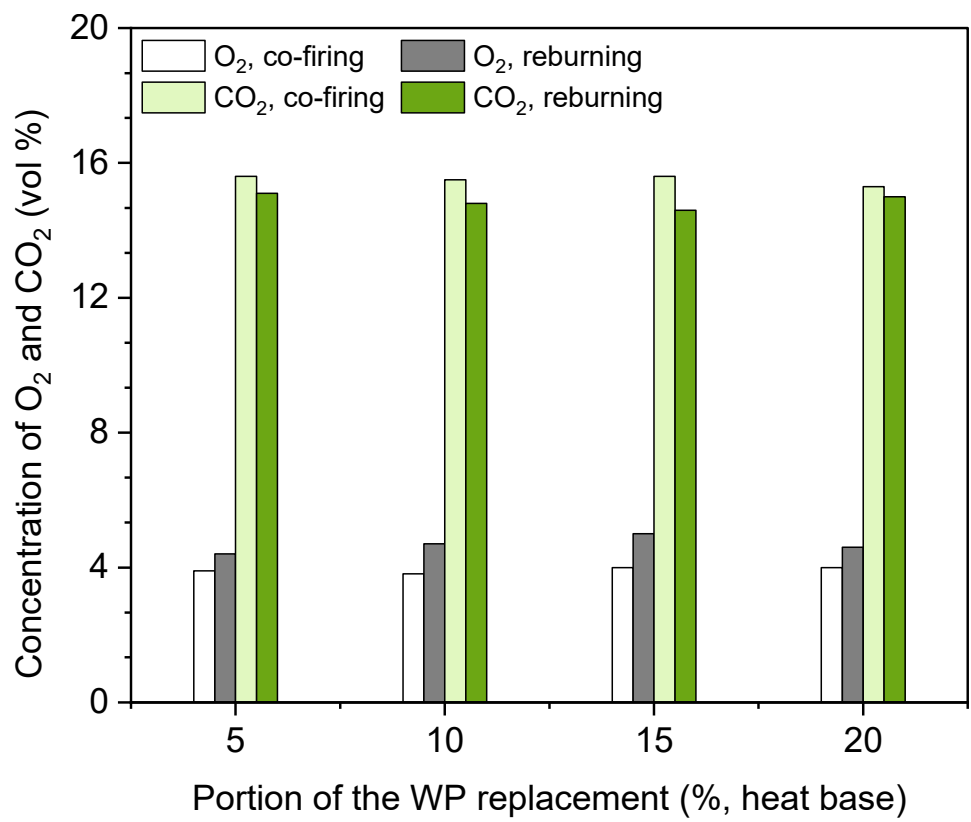

(a)

Figure 3. Cont. 


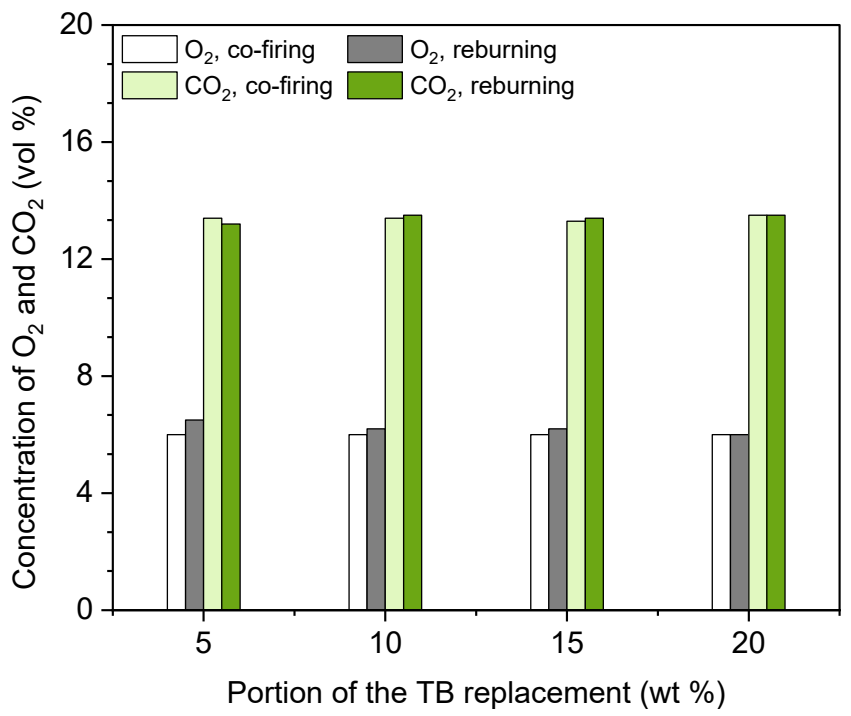

(b)

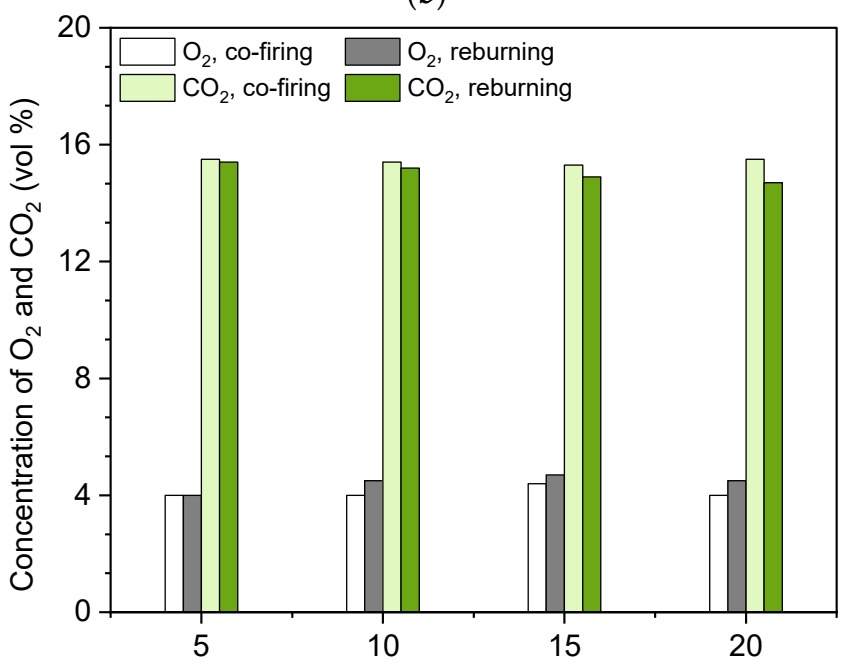

Portion of the EFB replacement (\%, heat base)

(c)

Figure 3. $\mathrm{O}_{2}$ and $\mathrm{CO}_{2}$ concentrations at furnace exit for various WP cofiring and reburning ratios: (a) wood pellet (WP), (b) torrefied biomass (TB), and (c) empty fruit bunch (EFB).

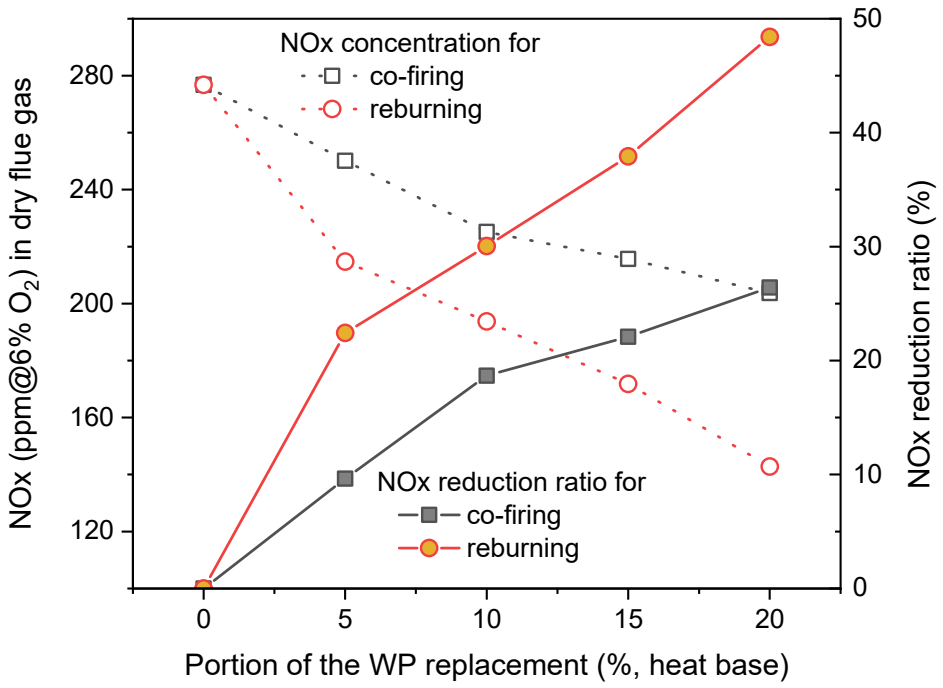

Figure 4. NOx emission and degree of NOx reduction for various WP cofiring and reburning ratios. 
Figure 5 shows the amount of NOx emission in ppm for cases with TB cofiring/reburning and the percent of NOx reduction compared to the base case. In the case of cofiring, we see a mild NOx reduction from $250 \mathrm{ppm}$ to $239 \mathrm{ppm}$ as the cofiring ratio is increased from $5 \%$ to $20 \%$. These correspond to $9 \%$ to $13 \%$ NOx reduction as compared to the base case. Therefore, using TB as cofiring fuel is not an effective primary NOx reduction strategy. On the other hand, reburning of the TB shows an effective NOx reduction capability. The reburning line shows steep reduction in NOx as the reburning ratio is increased from 5\% to $20 \%$. The value of NOx emission for $5 \%$ to $20 \%$ reburning is $220 \mathrm{ppm}$ to $149 \mathrm{ppm}$. These numbers correspond to $20 \%$ to $46 \%$ NOx reduction when compared with the base case.

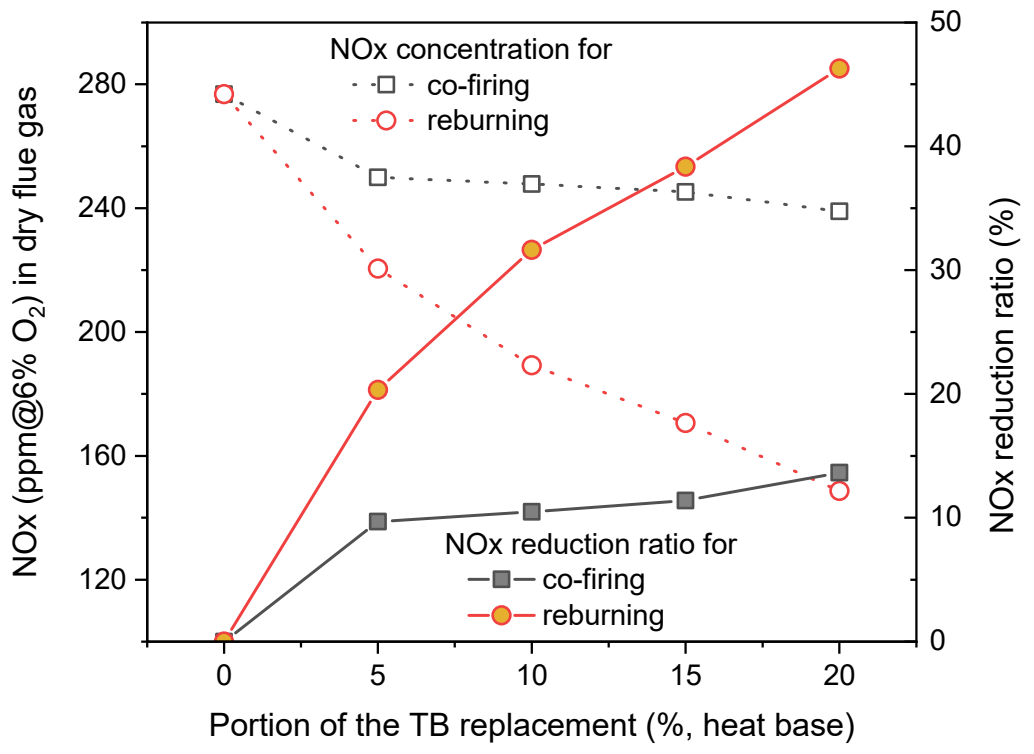

Figure 5. NOx emission and degree of NOx reduction for various TB cofiring and reburning ratios.

Another important discussion could be developed by comparing Figure 4 with Figure 5. As it has been said in the previous paragraph, the NOx reduction capability of TB in reburning technology is, by far, higher than cofiring technology. The explicit numbers of $20 \%$ to $46 \%$ NOx reduction capability in reburning technology versus $9 \%$ to $13 \%$ NOx reduction in cofiring technology when the fuel substitution varies from $5 \%$ to $20 \%$ proves the significantly different performance between the two technologies. On the other hand, Figure 4 shows almost parallel black and red lines for the WP replacements of $5 \sim 20 \%$, which implies there might be a relation between NOx abatement capability of biomass in reburning and cofiring technologies. However, Figure 5 rejects such a hypothesis. Indeed, biomass cofiring and reburning technologies abate NOx through totally different mechanisms. In cofiring, the emphasis is on higher volatile matter of biomass compared with coal. This higher volatile matter changes the heating rate and ignition behavior of coal. This, in turn, leads to shifting more fuel-N toward volatile-N, as opposed to char-N. Volatile-N, which is usually in forms of $\mathrm{NH}_{3}$ and $\mathrm{HCN}$, has NOx abatement capability in an oxygen deficient environment [30]. In reburning, on the other hand, the emphasis is on the shifting of fuel from the primary combustion zone to the higher levels, in order to make a locally fuel-rich, oxygen-deficient region. Such a region produces $\mathrm{CH}_{\mathrm{i}}$ and $\mathrm{C}-\mathrm{O}$ fragments, which could be partnered with $\mathrm{NO}$ and, finally, lead to $\mathrm{N}_{2}$ through chain reactions. Therefore, unlike cofiring, reburning technology does not necessarily require a high volatile matter fuel. It is very interesting to see that TB as cofiring has a much lower NOx abatement capability than WP (comparison between continuous black lines in Figures 4 and 5). However, as reburning fuel, TB and WP have quite similar NOx reduction performance in Figures 4 and 5. To be explicit in numbers, increasing the reburning ratio from 5\% to $20 \%$ reduces NOx from $220 \mathrm{ppm}$ to $149 \mathrm{ppm}$ for TB and from 214 to 140 for WP. That is while TB has a higher fuel ratio (i.e., 0.361 versus 0.080$)$ and lower volatile $(70.9 \%$ versus $83.9 \%$ ). The slightly higher NOx emission in TB might be due to the much higher 
fuel ratio. This clearly shows that reburning is less sensitive to fuel ratio, volatile matter, and ignition behavior of fuel compared to cofiring technology if a quite large retention time in the reburn zone is applied (around $1.5 \mathrm{~s}$ in this study). The issue of residence time becomes important when it comes to the dependency of NOx abatement on reburn fuel characteristics. It is logical to assume high volatile fuels with higher heating rates need less time to liberate all of their NOx reduction agents compared to low volatile fuels. However, when the residence time becomes large enough, the influence of volatile matter becomes blurred. Previous research $[12,22,27,29]$ emphasized on the importance of volatile matter of reburn fuel have applied smaller residence time: $0.4 \mathrm{~s}, 0.5 \mathrm{~s}, 0.6 \mathrm{~s}$, and $0.8 \mathrm{~s}$, respectively.

Figure 6 shows the amount of NOx emission and percent of NOx reduction compared to the base case for EFB cofiring and reburning cases. Cofiring of $5 \%$ to $20 \%$ leads to a reduction in NOx emission from 252 to 222 . These numbers correspond to $9 \%$ to $20 \% \mathrm{NOx}$ reduction compared to the base case. On the other hand, $5 \%$ to $20 \%$ reburning leads to a reduction in NOx from 210 to 140, which corresponds to $24 \%$ to $50 \%$ NOx reduction.

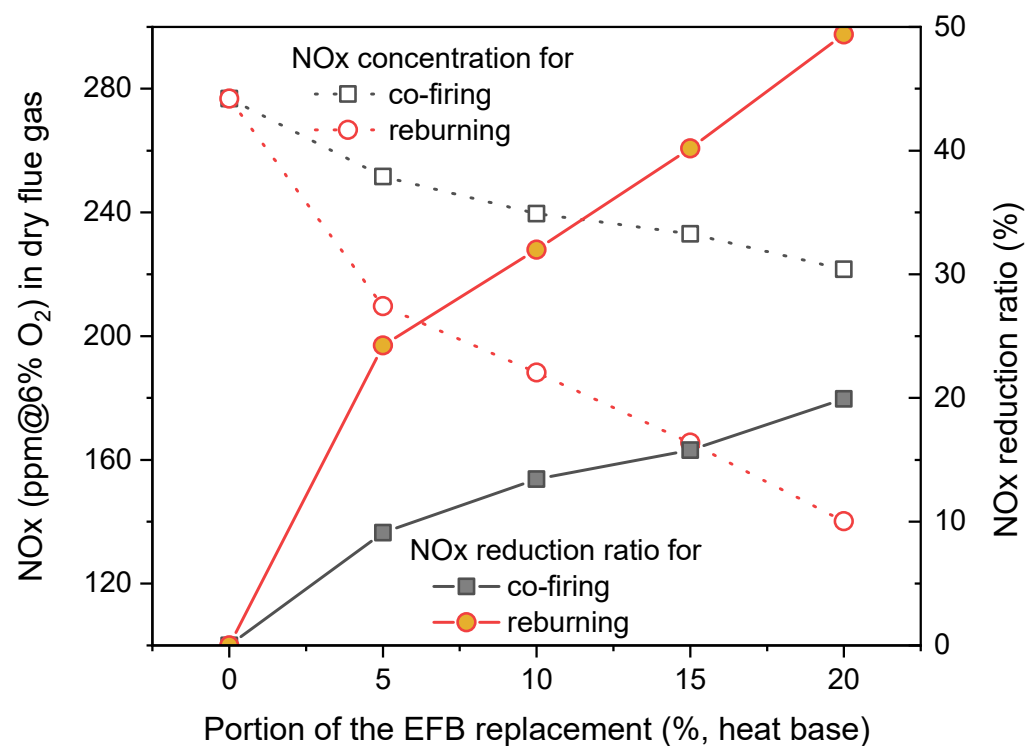

Figure 6. NOx emission and degree of NOx reduction for various EFB cofiring and reburning ratios.

Another discussion could be established by comparing results of cofiring and reburning in all three biomasses. On the cofiring side (comparing the continuous dotted line in Figures $4-6$ ), $5 \%$ to $20 \% \mathrm{WP}, \mathrm{TB}$, and EFB cofiring leads to NOx reduction from 250 to 203, from 250 to 239, and from 251 to 222, respectively. On the reburning side (comparing the dotted red line in Figures 4-6), 5\% to 20\% reburning leads to NOx reduction from 214 to 140, from 220 to 149 , and from 210 to 140 for WP, TB, and EFB, respectively. It is clear that altering fuel leads to significantly higher variation in NOx reduction for cofiring cases than reburning cases. Indeed, altering fuel in reburning technology leads to quite a similar amount of NOx reduction. That is while EFB has a fuel ratio three times higher than WP and fuel-N lower than WP and TB. Therefore, it could be concluded that reburning technology with regard to NOx reduction is less sensitive to fuel type than cofiring technology.

\subsection{NOx Reduction Effectiveness of Reburning versus Cofiring}

Figure 7 shows the NOx reduction effectiveness for cofiring and reburning of all biomasses used in this study. The term NOx reduction effectiveness has been defined in the Part 1 paper as the ratio between the percent of NOx reduction and the percent of biomass replacement on a thermal basis (either as cofiring or reburning fuel). We see that in both cofiring and reburning cases, higher fuel replacement leads to lower NOx reduction effectiveness. This means that the highest NOx reduction effectiveness happens at the lowest cofiring/reburning ratios. This conclusion has been previously made in the Part 1 paper for biomass cofiring, and it implies that a continuous low cofiring ratio is more 
advantageous than a periodic high cofiring ratio with regard to NOx abatement. In this paper, we see that the same conclusion could be made for reburning cases. In addition, we can reveal that levels of NOx reduction effectiveness for reburning cases are considerably higher than those of cofiring. As the reburning ratio increases from $5 \%$ to $20 \%$, the NOx reduction effectiveness ranges from 4.5 to 2.5 (for WP), 4.1 to 2.3 (for TB), and 4.9 to 2.5 (for EFB). That is while the same level of increase in cofiring ratio leads to NOx reduction effectiveness ranging from 1.9 to 0.7 . It shows that reburning of biomass fuels is definitely a more effective option than cofiring to reduce NOx emission when the same amount of the biomass fuel is replaced. The NOx reduction effectiveness of reburning can be $2.4 \sim 2.7$ times higher than the effectiveness of cofiring.

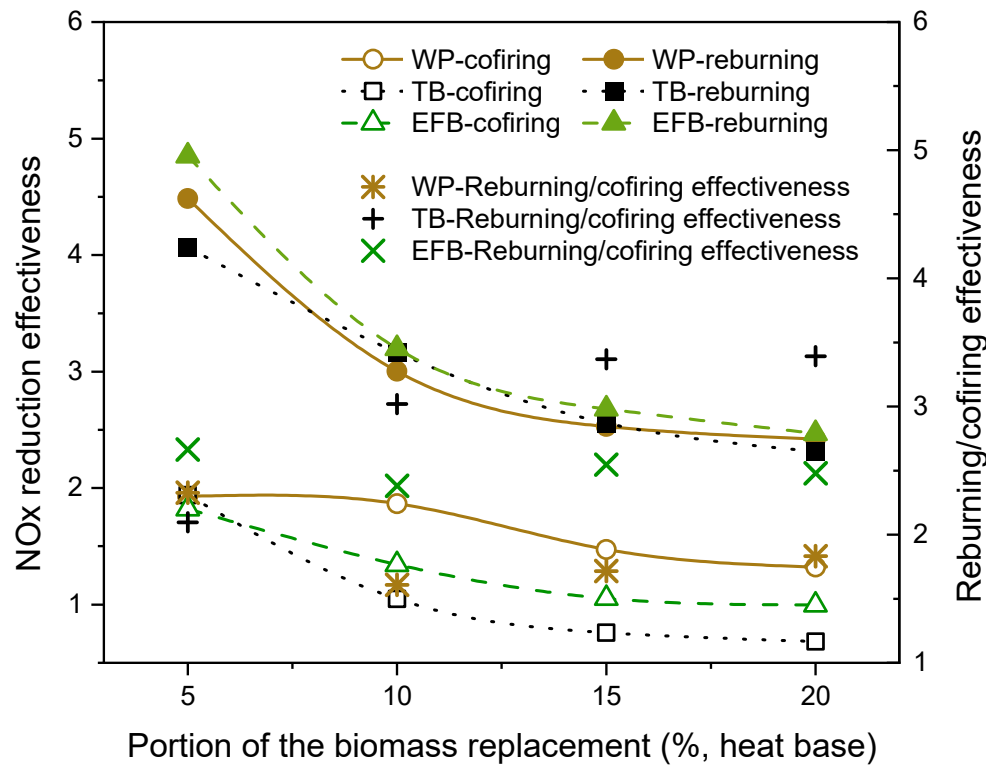

Figure 7. NOx reduction effectiveness and effectiveness ratios of reburning over cofiring for various types and replacement ratios of the biomasses.

Another remarkable point is the fact that NOx reduction effectiveness by increase in biomass reburning shows an exponential decay behavior. Spliethoff et al. [31] reported such NOx reduction behavior against air staging level. Even though the level of air staging between burner/reburn port and overfire air is constant for all cases, increasing the reburning/cofiring ratio leads to an increase in volatile matter in the oxygen-deficient zones because biomass has more volatile matter than coal. This virtually intensifies the air staging effect. However, in terms of the NOx reduction, reburning is far more efficient than cofiring in our experimental conditions. It seems to be due to the fact that the local stoichiometric ratio in the reburning zone is controlled only by amounts of reburn fuel and overfire air. It is less affected by burner design parameters because the NOx reduction zone is separated from the burner zone. However, the NOx reduction zone in the cofiring cases is in the burner zone. The local stoichiometric ratio in there could be affected significantly by parameters on the burner design, including combustion characteristics of the fuel. This can be supported by the reburning data that the effectiveness is not highly dependent on fuel types. They show a similar level regardless of fuel ratio, while effectiveness of cofiring cases shows considerable differences for various types of biomass. This makes a significant difference in ratios of the NOx reduction effectiveness in reburning over cofiring for various fuel ratios.

The right $y$-axis of Figure 7 shows the ratio between reburning and cofiring NOx reduction effectiveness. WP has the lowest fuel ratio (0.08), and the ratio is in the range of 1.6 to 1.9 , while TB (fuel ratio: 0.34 ) cases are in the range of 2.1 and 3.5. In addition, the EFB (fuel ratio: 0.24 ) cases are located in between (2.4 2.6). The difference becomes clearer for higher replacement of the biomass. As shown in the effectiveness graph, it is caused by the 
fact that NOx is not effectively reduced when a high fuel ratio biomass is cofired. Through this analysis, we can conclude that the biomass with relatively low volatile contents can be more effectively utilized when it is applied for reburning rather than cofiring.

\section{Conclusions}

In this study wood pellet, torrefied biomass, and empty fruit bunch are utilized as reburn fuel to investigate the impact of fuel characteristics and reburning ratio on NOx reduction. Furthermore, these reburning cases are compared with cofiring cases in the Part 1 paper in order to establish a platform for cost-benefit analysis of the two technologies (i.e., reburning versus cofiring) on a consistent basis when it comes to NOx reduction potentials. The significant findings of this study are outlined as follows:

- Reburning leads to significantly higher NOx reduction than cofiring. The NOx reduction effectiveness of reburning technology can be 3.4 times higher than the NOx reduction effectiveness of cofiring technology, depending on the biomass fuel characteristics. The NOx reduction effectives in reburning technology can be as high as 4.9.

- NOx reduction effectiveness reduces exponentially as the reburning ratio increases. Therefore, continuous low reburning ratios are more cost-efficient than periodic high reburning ratios.

- For WP and EFB, reburning leads to lower fuel conversion than cofiring cases, which is the drawback of using reburning technology for NOx reduction compared to cofiring technology.

- With the large residence time applied in this study, NOx reduction in reburning technology depends less on fuel properties, such as fuel ratio or amount of fuel-inherited nitrogen. It is observed that the three biomasses with different fuel characteristics led to quite similar NOx reduction through reburning technology. This is in opposition with the cofiring technology, which highly depends on fuel characteristics, and especially the amount of volatile matter.

Author Contributions: Conceptualization, W.Y. and C.R.; methodology, W.Y.; validation, Y.L.; formal analysis, J.L.; data curation, T.C.; writing-original draft preparation, T.C.; writing-review and editing, T.C.; project administration, W.Y.; funding acquisition, W.Y. All authors have read and agreed to the published version of the manuscript.

Funding: The Korea Institute of Energy Technology Evaluation and Planning (KETEP) grant funded by the Korean government (MOTIE) (20193410100050, Development of novel pollutant removal process from combustion gas using low-temperature deNOx system), Korea Institute of Industrial Technology (KITECH) grant as an International Collaborative R\&D Program (KITECH-JE-21-0022).

Institutional Review Board Statement: Not applicable.

Informed Consent Statement: Not applicable.

Acknowledgments: This work was supported by the Korea Institute of Energy Technology Evaluation and Planning (KETEP) grant funded by the Korean government (MOTIE) (20193410100050, Development of novel pollutant removal process from combustion gas using low-temperature deNOx system) and by Korea Institute of Industrial Technology (KITECH) grant as an International Collaborative R\&D Program (KITECH-JE-21-0022).

Conflicts of Interest: The authors declare no conflict of interest.

\section{References}

1. Baxter, L.L.; Mitchell, R.E.; Fletcher, T.H.; Hurt, R.H. Nitrogen release during coal combustion. Energy Fuels 1996, $10,188-196$. [CrossRef]

2. Albrecht, W. NOx emissions from pulverised coal flames. Vgb Kraftw. Engl. Issue 1993, 72, 564-571.

3. Reidick, H.; Kessel, W.; Fritz, P.; Hein, K. In-furnace NOx reduction of selected brown coal-fired steam generators. Vgb Kraftw. Engl. Issue 1991, 71, 400-404.

4. Nussbaumer, T. Wood combustion. In Advances in Thermochemical Biomass Conversion; Blackie Academic \& Professional: London, UK, 1994; ISBN 07514 01714; pp. 575-589. 
5. Nussbaumer, T. Combustion and co-combustion of biomass: Fundamentals, technologies and primary measures for emission reduction. Energy Fuel 2003, 17, 1510-1521. [CrossRef]

6. Pershing, D.W.; Wendt, J.O.L. Relative contributions of volatile nitrogen and char nitrogen to NOx emissions from pulverised coal flames. Industrial and Engineering Chemistry Process. Des. Dev. 1979, 18, 60-66.

7. Aarna, I.; Suuberg, E.M. A review of the kinetics of the nitric oxide-carbon reaction. Fuel 1997, 76, 475-491. [CrossRef]

8. Cahill, P.; Smith, M.; Vallender, S.J. Characterisation of British coals for low NOx combustion. In Proceedings of the 1991 International Conference on Coal Science, Newcastle-upon-Tyne, UK, 16-20 September 1991.

9. Reed, R.D. Process for the disposal of nitrogen oxide. John Zink Company, US Patent 1,274,637, 1969.

10. Wendt, J.O.L.; Sternling, C.V.; Matovich, M.A. Reduction of Sulfur Trioxide and Nitrogen Oxides by Secondary Fuel Injection; 14th International Symposium on Combustion; The Combustion Institute: Pittsburgh, PA, USA, 1973.

11. Myerson, A.L.; Taylor, F.R.; Faunce, B.G. Ignition Limits and Products of the Multistage Flames of Propane-Nitrogen Dioxide Mixtures; 6th International Symposium on Combustion; The Combustion Institute: Pittsburgh, PA, USA, 1957.

12. Harding, N.S.; Adams, B.R. Biomass as a reburning fuel: A specialized co-firing application. Biomass Bioenergy 2000, 19, 429-445. [CrossRef]

13. Lewis, R.D. Three-Stage Combustion (Reburning) Test Results From a 300-MW Boiler in the Ukraine. In Proceedings of the 1993 Joint Symposium on Stationary Combustion NOx Control, Miami Beach, FL, USA., 24-27 May 1993.

14. Seu, S.W.H.; Castaldini, C.; Neuffer, W.J.; Durkee, K.R. Retrofit NOx Controls for Existing Industrial, Commercial, and Institutional Boilers: Status of Technologies and Cost Effectiveness. In Proceedings of the 1993 Joint Symposium on Stationary Combustion NOx Control, Miami Beach, FL, USA, 24-27 May 1993.

15. Okigami, N.; SekiGuchi, Y.; Miura, Y.; Sasaki, K.; Tamura, R. Three Stage Pulverized Coal Combustion System for In-furnace NOx Control. In Proceedings of the 1985 Joint Symposium on Stationary Combustion NOx Control, Boston, MA, USA, 6 May 1986.

16. Chen, S.L.; McCarthy, J.M.; Clark, W.D.; Heap, M.P.; Seeker, W.R.; Pershing, D.W. Bench and Pilot Scale Process Evaluation of Reburning for In-furnace NOx Reduction. In Proceedings of the 21st International Symposium on Combustion, Pittsburgh, PA, USA, 3-8 August 1986.

17. Adams, B.R.; Harding, N.S. Reburning using biomass for NOx control. Fuel Process. Technol. 1998, 54, 249-263. [CrossRef]

18. Ma, J.; Shen, J.; Liu, J.; Ma, Y.; Jiang, X. Reburning study of superfine pulverized coal in high $\mathrm{CO}_{2}$ concentration. Fuel 2018, 220, 25-31. [CrossRef]

19. Furusawa, T.; Tsunoda, M.; Tsujimura, M.; Adschiri, T. Nitric oxide reduction by char and carbon monoxide: Fundamental kinetics of nitric oxide reduction in fluidized bed combustion of coal. Fuel 1985, 64, 1306-1309. [CrossRef]

20. Ballester, J.; Ichaso, R.; Pina, A.; Gonzalez, M.A.; Jimenez, S. Experimental evaluation and detailed characterization of biomass reburning. Biomass Bioenergy 2008, 32, 959-970. [CrossRef]

21. Maly, P.M.; Zamansky, V.M.; Ho, L.; Payne, R. Alternative fuel reburning. Fuel 1999, 78, 327-334. [CrossRef]

22. Rudiger, H.; Kicherer, A.; Greul, U.; Spliethoff, H.; Hein, K.R.G. Investigations in combined combustion of biomass and coal in power plant technology. Energy Fuels 1996, 10, 789-796. [CrossRef]

23. Lopez, C.; Maier, J.; Hein, K.R.G. NOx Reduction by Solid Fuel Reburning: Pilot Scale Investigations; IEA Conference: Clean Coal Technologies for Our Future; IEA Clean Coal Center: London, UK, 2002.

24. Casaca, C.; Costa, M. NOx control through reburning using biomass in a laboratory furnace: Effect of particle size. Proc. Combust. Inst. 2009, 32, 2641-2648. [CrossRef]

25. Vilas, E.; Skifter, U.; Jensen, A.D.; Lopez, C.; Maier, J.; Glarborg, P. Experimental and modeling study of biomass reburning. Energy Fuels 2004, 18, 1442-1450. [CrossRef]

26. Shu, Y.; Wang, H.; Zhu, J.; Tian, G.; Huang, J.; Zhang, F. An experimental study of heterogeneous NO reduction by biomass reburning. Fuel Process. Technol. 2015, 132, 111-117. [CrossRef]

27. Hodzic, N.; Kazagic, A.; Smajevic, I. Influence of multiple air staging and reburning on NOx emissions during co-firing of low rank brown coal with woody biomass and natural gas. Appl. Energy 2016, 168, 38-47. [CrossRef]

28. Lu, P.; Wang, Y.; Huang, Z.; Lu, F.; Liu, Y. Study on NO reduction and its heterogeneous mechanism through biomass reburning in an entrained flow reactor. Energy Fuels 2011, 25, 2956-2962. [CrossRef]

29. Zhou, W.; Swanson, L.; Moyeda, D.; Xu, G. Process evaluation of biomass co-firing and reburning in utility boilers. Energy Fuels 2010, 24, 4510-4517. [CrossRef]

30. Brouwer, J.; Heap, M.P.; Bales, F.E.; Brouwer, J.; Heap, M.P.; Bales, F.E. The Use of Wood as a Reburning Fuel in Combustion Systems. In Proceedings of the 6th national bioenergy conference, Reno, NV, USA, 2-6 October 1994.

31. Spliethoff, H.; Gruel, U.; Rüdiger, H.; Hein, K.R.G. Basic effects on NOx emissions in air staging and reburning at a bench-scale test facility. Fuel 1996, 75, 560-564. [CrossRef] 